石油技術協会誌 第 60 巻 第 5 号 (平成 7 年 9 月)

JOURNAL OF THE JAPANESE ASSOCIATION FOR PETROLEUM TECHNOLOGY

VOL. 60 , NO. 5 (Sept, 1995)

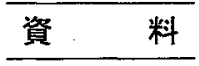

\title{
大水深掘削セミサブリグの概要*
}

\author{
中村 雅洋**・横倉 浩三**. 中村 新*** ・ 野口 雅毅***
}

(Received July 7, 1995 : accepted July 11, 1995)

\section{Activity of semisubmersible drilling rig in deepwater}

\author{
Masahiro Nakamura, Kozo Yokokura, Arata Nakamura and Masaki Noguchi
}

\begin{abstract}
An analysis of worldwide offshore drilling activities shows a clear trend towards deepwater. Advances in deepwater petroleum production are also continuing, with primary areas of activity currently in the Gulf of Mexico and offshore Brazil. As well, the Voring Plateau in offshore Norway and the West Shetlands show promise as the next deepwater frontiers. Although there are potential hydrocarbon resources in offshore deepwater Japan, there has not yet been any activity deeper than $500 \mathrm{~m}$, and there are no deepwater rigs owned or operated Japanese companies.

The technological challenges of drilling for or producing hydrocarbons in deepwater are formidable. The science involved is evolving rapidly, but the rapid changes also mean that there is no standard or established technology.

With future needs in Japan, further exploratory markets worldwide, and a technological opening, a nexus of opportunities for a Japanese deepwater rig currently exist. Taking advantage of this opportunity would allow Japan to develop a world class deepwater experience base and technology level, and give Japan advantages for research and development in all deepwater engineering fields.

This paper describes the current world activity level in deepwater, and outlines some of the crucial technologies that can be developed.
\end{abstract}

\section{1.はじめに}

大水深掘削技術の現状について述べるにあたって，ま ず我が国ならびに世界の海洋掘削に関する各種のデータ を調查して，現状を把握することにする。そして，海洋 掘削システムおょび掘削技術の基礎となる其体的な事例 を示し，大水深技術の可能性について述べる。

$*$ 平成 7 年 6 月 8 日, 平成 7 年度石油技術協会春季講演会作井 部門シンポジゥム「海洋におけるオペレーション」で講演 This paper was presented at the 1995 JAPT Drilling Technology Symposium entitled "Offshore Operation", heid in Makuhari, Chiba, Japan, June, 8, 1995.

** 日本海洋崡削株式会社エンジニアリング事業部 Engineering Division, Japan Drilling Co., Ltd.

***石油公団技術部開発技術㹎 Technical Department, Development Division. Japan National Oil Corporation

Copyright (C) 1995, JAPT
近年の海洋油田開発は，大水深化汃つ小規模化の傾向 にあり，石油開発会社は大水深対応掘削・生産に関する 技術開発を積極的に取り組んでいる。例えば, Texaco 社は共同開発形態で多数のオイルカンパニーが参加した 「Deep Star」プロジェクトにおいて大水深技術開発を 進めている。また，Petrobras 社は「Procap 2000」プ ロジェクトにおいて同様に水深 $2,000 \mathrm{~m}$ を目標に開発 を進め, Campos/Santos Basin における大水深開発に その成果を活用すべく，すでに大水深掘削・生産の可能 性に挑戦する研究開発を進めている。さらに, 両プロ ジェクトは成果の共有を計画している。このような情勢 下，我が国の技術レベルの低迷を打破すべく我が国先端 技術を有効に活用させるテーマとして「大水滐掘削」を 位置付ける意義は大きいと考えられる。

大水深技術の世界記録は水深 2,328 $\mathrm{m}$ における Shell 社の掘削が広く知られている。水深 $2,000 \mathrm{~m}$ に対応す 
る技術は既存技術と考えられがちであるが，解決す心゙き 課題について様々な状況下における検討を加え，さらに 実機に扔ける経験によって汎用性・信頼性を生み出すこ とができると考えられる。このような汎用性・信頼性の ある大水深技術に挑戦して国際的に䰠力ある基礎技術を 研究し，応用技術の発展に努めることが我が国に求めら れている。

\section{2. 大水深技術の確立}

大水深技術は，海洋に係わる究極技術であると言え る。さらに，大水深において視認できない海底下を掘り 抜く技術および大水深における浮体定点保持は，海洋掘 削における重要な分野であり，超大水深におけるこれら の技術はまったく未知の世界であると言える。これらの 技術開発の成果は，様々な分野に芯用技術として寄与で きるもの之考えられる。

さて，大水梁技術とはいかなるものであろう。まず， 大水梁の定義について考えると，それは技術の進歩に応 じて変化するものであると言える。したがって，現時点 における技術レベルを鑑みて，「大水深とは水深 $500 \mathrm{~m}$ 以樑 $2,000 \mathrm{~m}$ 以下を言い, 水樑 $2,000 \mathrm{~m}$ 以上は超大水 深と言う」と定義する。

大水深技術は様々な要素技術の集合体であり，かつ総 合評価技術が加元られなければ実際的なハードは生み出 すことができないと考えられる。また，ソフトウェアの 充実, ハードウェアの運用は, 様々な分野の強力なバッ クアップを必要とする。

\section{3，海洋石油技術}

\section{1 海洋掘削りグの現状}

ここでは，海洋石油掘削りグの現状を把握するため に，海域別に海洋掘削りグの稼働状態をまとめた（表 1)。表 1 から現在の主な石油開発海域は, メキシコ湾, 北海, 南アメリカ扔よび東南アジアであることがわか る。また，海洋石油掘削りグ別では，ジャッキアップ型 が60\%，セミサブ型が22\%を占める。また，全リグの契 約率は，73\%（1995年 2 月現在）である。現状では，海 洋石油掘削市況の回復力は，まだ弱いと言える。

次に1987年以降の稼働実績の推移を図 1 に示す。図 1 は，リグ総数（コンペティティリグ，稼働リグ数およ び油価（WTI 石油価格）についてプロットしたもので ある。

図 1 から油洒と稼動りグ総数に 1 次の相関関係がある ことがわかる。現在油価が20 \$以下で推移することによ る開発意欲の低迷拈よび掘削りグのデーレート（日割り 料率）の低迷あるいは船齢による廃船・転用のために， リグ総数が減少して需要・供給が適正値に収束しつつあ ることが読み取れる。1970年代後半から1980年代前半の リグ建造ラッシュによる供給過剩に起因する稼働率低迷 と, 第 2 次オイルショック後の石油開発低迷によるダブ ルパンチを是正しながら推移してきた業界の緩やかな稼 働率の上昇シナオリは，依然として完全な回復までには 程遠い。リグ総数は毎年減少しているが油価，デーレー 卜の回復は芳しくなく，ここ数年は緩やかに需要・供給

表 1 海洋石油開発掘削リグ

(Offshore Rig Locator, ODS, 1995/2)

\begin{tabular}{|c|c|c|c|c|c|c|c|c|c|c|c|c|}
\hline \multirow{2}{*}{ Area } & \multirow{2}{*}{ Total } & \multirow{2}{*}{$\begin{array}{l}\text { Under } \\
\text { Contract } \\
\text { Drilling } \\
\end{array}$} & \multirow{2}{*}{$\begin{array}{c}\text { No } \\
\text { Working } \\
\text { Contract }\end{array}$} & \multirow{2}{*}{$\begin{array}{l}\text { No Con- } \\
\text { tract }\end{array}$} & \multicolumn{2}{|c|}{ Jackup } & \multicolumn{2}{|c|}{ Semi-Sub } & \multicolumn{2}{|c|}{ Ship } & \multicolumn{2}{|c|}{ Others } \\
\hline & & & & & Working & \begin{tabular}{|c|c|} 
Not \\
Working
\end{tabular} & Working & $\begin{array}{c}\text { Not } \\
\text { Working }\end{array}$ & Working & \begin{tabular}{|c|} 
Not \\
Working
\end{tabular} & Working & $\begin{array}{c}\text { Not } \\
\text { Working }\end{array}$ \\
\hline Gulf Of Mexico & 197 & 134 & 3 & 60 & 112 & 44 & 15 & 12 & 1 & 1 & 6 & 6 \\
\hline North Sea & 88 & 68 & 10 & 10 & 39 & 7 & 29 & 13 & 0 & 0 & 0 & 0 \\
\hline Asia & 94 & 74 & 8 & 12 & 28 & 8 & 25 & 8 & 4 & 2 & 0 & 0 \\
\hline South America & 92 & 79 & 3 & 10 & 18 & 9 & 15 & 3 & 4 & 0 & 42 & 1 \\
\hline Middle East & 57 & 42 & 4 & 11 & 42 & 14 & 0 & 0 & 0 & 0 & 0 & 1 \\
\hline Africa & 46 & 31 & 6 & 9 & 17 & 5 & 7 & 6 & 2 & 1 & 5 & 3 \\
\hline Indian & 29 & 25 & 0 & 4 & 21 & 2 & 0 & 1 & 3 & 1 & 1 & 0 \\
\hline Mediterranean & 15 & 12 & 2 & 1 & 8 & 2 & 3 & 1 & 1 & 0 & 0 & 0 \\
\hline CIS & 23 & 10 & 13 & 0 & 6 & 6 & 3 & 4 & 1 & 3 & 0 & 0 \\
\hline Canada/Alaska & 9 & 1 & 4 & 4 & 1 & 2 & 0 & 0 & 0 & 1 & 0 & 5 \\
\hline \multirow[t]{2}{*}{ Total } & 650 & 476 & & 121 & 292 & 99 & 97 & 48 & 16 & 9 & 54 & 16 \\
\hline & 650 & & & & & 391 & & 145 & & 25 & & 70 \\
\hline Working Ratio & & 73 & & & & 75 & & 67 & & 64 & & 77 \\
\hline Rate (\%) & & & & & & 60 & & 22 & & 4 & & 11 \\
\hline
\end{tabular}




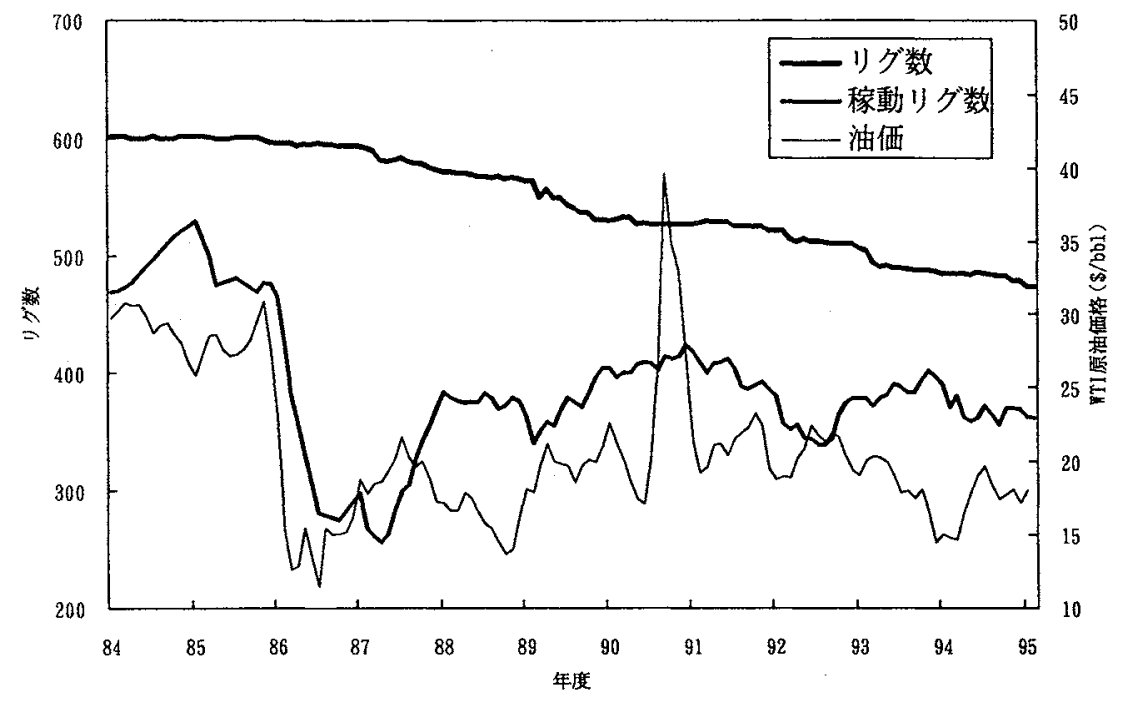

図 1 海洋石油掘削リグの稼働実績

の適正值に向かうと考えられる。このままで推移すると 2000 年ごろに需要と供給のバランスがとれる見通しであ り，急激な回復は見込めないと考えられる。したがっ て，コントラクターがリグの建造に関してジレンマに 宿っているのが現状であろう。

参考のために世界のドリリングコントラクターの所有 リグ数について調查した結果を表 2 に示す。これによれ ば，業界の再編あるいは廃船などによるリグ総数の変化 が現れている。特に著明なコントラクターの買収あるい は生産プラットフォームへの転用が目立っている。

\section{2 大水深技術の現状}

(1) 大水深掘削

世界最大水樑記録は，泥水幅環を伴わない掘削システ ムを適用している Ocean Drillig Program（ODP）を除 いて, Shell 社が1988年にメキシコ沙で記録した 2, $328 \mathrm{~m}$ である。コントラクターは, Sonat 社であり, 海 洋据削リグは, 船型 DPS の Discoverer 7 Seas である。 また半潜水型 DPS では, Sedco 709 の水深 1,592 m, 半潜水型チェーン・ワイヤー係留では, Ocean America の水深 1,416 m が最大水深記録である。1,000 $\mathrm{m}$ 以 上の撽削において顕著な海域はブラジルおよびメキシコ 湾である。他の海域では北海周辺の Voring Plateauあ るいはシェトランド諸島の西側海域および西アフリカ沿 岸が有力な大水深海域であり, 東南了ジアにおいては, インドネシア，フィリピンにおいて大水深掘削が計画さ れている。

一方，我が国では，基礎試錐において石油資源開発株 式会社が1983年に御前崎沖で記録した $469 \mathrm{~m}$ が最大水
深である。コントラクターは日本海洋掘削株式会社であ り，掘削りグは第 5 白竜 (半潜水型チェーン係留) であ る。我が国はハード面からみて $500 \mathrm{~m}$ 以深対応の半潜 水型・船型掘削リグは所有しておらず，世界加ら水を開 けられているのが現状である。世界の水深記録を図 2 に 示す。

（2）大水深生産システム

海洋における石油開発は，水深 $200 \mathrm{~m}$ 以浅の大陸棚 海域加ら永深 1,000 m を超える大陸棚斜面に向加って 発展している。このような情勢下, 開発・生産システム は，様々なコンセプトが実用化されている。従来のジャ ケットのほかにFloating Production System (FPS), Tension Leg Platform (TLP) およびロンプライアン トタワーが開発されている。図 3 に開発・生産システム を示す。表 3 に開発コンセプト別水深記録を示す。この 表からわかるとおり, 生産システムは水深 $1,000 \mathrm{~m}$ に 向けて開発が進んでいる。

\section{3 浮遊式生産システム (FPS)}

世界的に見て大水深・撖海域ならごに小規模油田にお いては，半潜水型生産システムを利用することが多い。 その事例は，北海怙よびブラジルが顕著である。ブラジ ルは政策的に早期キャシュフローを求める傾向が強く， また, Marlim,Albacora,Barracuda などの油田が大水 深のために FPS を活用している。世界の半潜水型生産 シテスムの事例を稼働水深順に15システムを選定して表 4 に，また夕ンカー型生産システム（FPSO）を表 5 に 示す。

FPS は, 生産処理設備を半潜水型浮体やタンカー型 
表 2 世界のドりリングコントラクター（Offshore Rig Locator, ODS, 1995/2)

\begin{tabular}{|c|c|c|c|c|c|c|c|c|}
\hline & ドリリングコントラクター & Jackup & Semi & Ship & Tender & Barge & Arctic & 合 計 \\
\hline 1 & Diamond Offshore & 16 & 25 & 1 & & & & 42 \\
\hline 2 & Noble Drilling & 31 & 8 & & & & & 39 \\
\hline 3 & Sedco Forex & 12 & 20 & 2 & 4 & & & 38 \\
\hline 4 & ENSCO & 23 & & & & 10 & & 33 \\
\hline 5 & Global Marine & 23 & 2 & 1 & & & & 26 \\
\hline 6 & Santa $\mathrm{Fe}$ & 21 & 3 & & & 1 & & 25 \\
\hline 7 & Rowan & 20 & 1 & & & & & 21 \\
\hline 8 & Sonat & 10 & 7 & 2 & & & & 19 \\
\hline 9 & Maersk & 10 & 3 & & & 4 & & 17 \\
\hline 10 & Reading \& Bates & 10 & 3 & & 2 & & & 15 \\
\hline 11 & Lagoven & & & & 1 & 13 & & 14 \\
\hline 12 & Falcon Drilling & 10 & 1 & & & 2 & & 13 \\
\hline 13 & Marine Drilling & 13 & & & & & & 13 \\
\hline 14 & Smedvig & 6 & 4 & & 3 & & & 13 \\
\hline 15 & Petrobras & 6 & 6 & & & & & 12 \\
\hline 16 & SOCAR & 6 & 5 & & & & & 11 \\
\hline 17 & ONGC & 8 & & 3 & & & & 11 \\
\hline 18 & Arethusa Offshore & 3 & 8 & & & & & 11 \\
\hline 19 & Maraven & 2 & & & 2 & 6 & & 10 \\
\hline 20 & National Drilling & 10 & & & & & & 10 \\
\hline 21 & Transocean & 3 & 6 & 1 & & & & 10 \\
\hline 22 & Dual & 10 & & & & & & 10 \\
\hline 23 & Foramer & 2 & & & 7 & & & 9 \\
\hline 24 & Bohai Drilling & 8 & & & & & & 8 \\
\hline 25 & Viking Rigs & 7 & & & & & & 7 \\
\hline 26 & Neddrill & 4 & 1. & 2 & & & & 7 \\
\hline 27 & Saipem & 4 & 3 & & & & & 7 \\
\hline 28 & IFESM Petromar & 7 & & & & & & 7 \\
\hline 29 & Atwood Oceanics & 1 & 5 & & 1 & & & 7 \\
\hline 30 & Sakhalinmor & 4 & 1 & 1 & & & & 6 \\
\hline 31 & Pool Offshore & 6 & & & & & & 6 \\
\hline 32 & Wilrig & & 6 & & & & & 6 \\
\hline 33 & Japan Drilling & 3 & 2 & & & & & 5 \\
\hline 34 & Canadian Marine & & & 2 & & & 3 & 5 \\
\hline 35 & Nanhai West Drilling & 2 & 3 & & & & & 5 \\
\hline 36 & Arctimor & 2 & 1 . & 2 & & & & 5 \\
\hline 37 & Cliffs & 5 & & & & & & 5 \\
\hline
\end{tabular}

浮体に搭載したものである。長所は，初期投資を抑え， リード夕イムが短く，再利用性が良いことが挙げられ る。この長所を生玑して小規模油田開発に用いられてい る。

半潜水型システムは，1975年に Hamilton 社が北海の Argyll 油田の水深 $76 \mathrm{~m}$ に設置したものが最初である。 半潜水型システムは, 眝油機能を持っていないのが一般 的で，パイプラインやFloating Storage Offloading （FSO）による出荷方法が利用される。半潜水型生産シ
ステムにおける最大水深は，1994年に設置された Marlim 油田の $910 \mathrm{~m}$ である。

タンカー型システムは，1977年に Shell 社が地中海の Castellon 油田の水深 $118 \mathrm{~m}$ に設置した Floating Production, Storage and Offloading (FPSO) が最初であ る。このタイプは海象・気象条件の穞やかな海域で利用 されている。近年タンカー型システムは，タレット式が 主流となっていることが特筆される。また，Petrobras 社が Barracuda 油田にタレット係留の FPSO を水深 


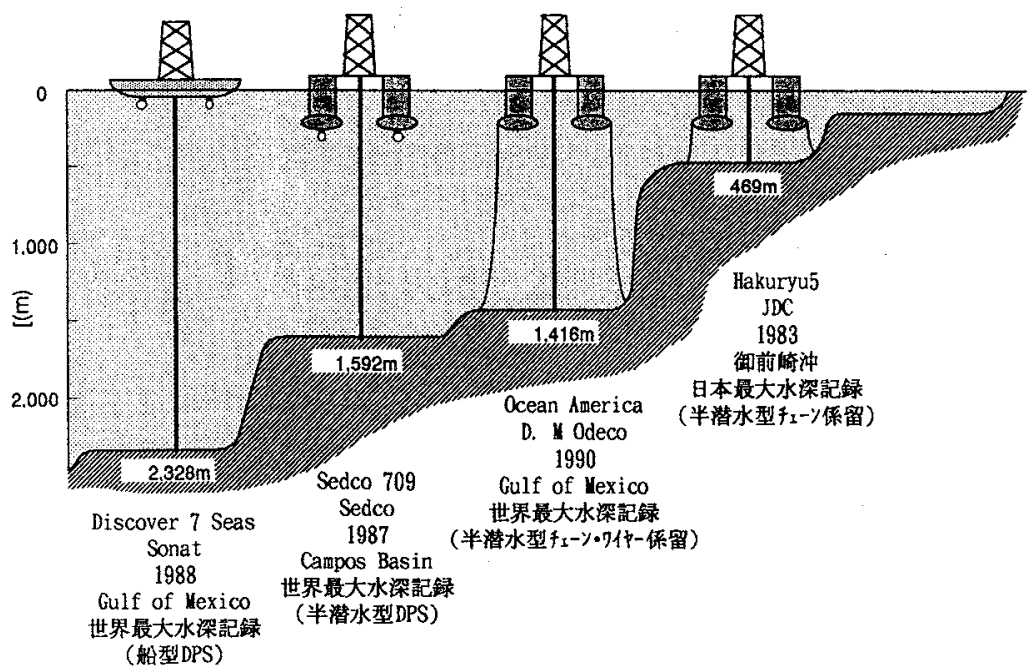

図 2 世界の水樑記録

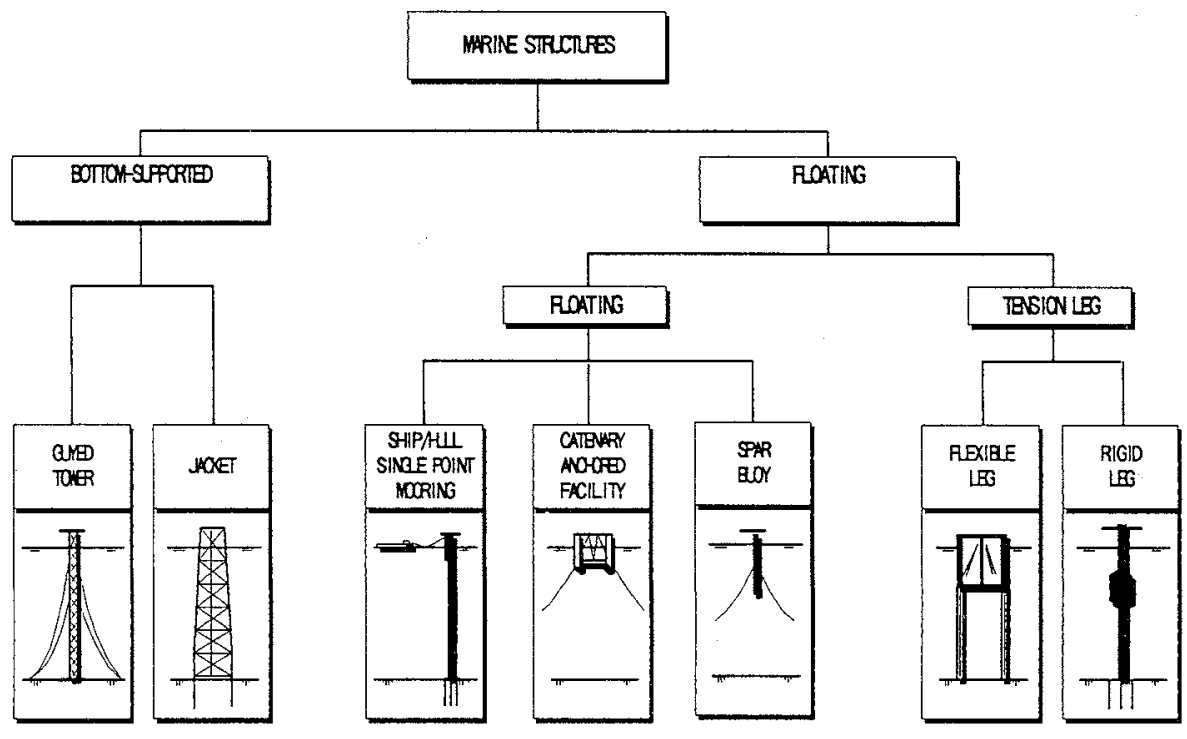

図 3 石油プラットフォームコンセプト

表 3 大水深に打ける各種石油プラットフォーム

\begin{tabular}{|l|l|l|c|c|}
\hline \multicolumn{1}{|c|}{ Type } & \multicolumn{1}{|c|}{ Operator } & \multicolumn{1}{|c|}{ Field } & W. D. (m) & Year \\
\hline Jacket-Steel & Shell & Bullwinkle & 410 & 1988 \\
Jacket-Concrete & Shell & Troll & 305 & 1995 \\
Compliant Tower & Exxon & Lena & 311 & 1983 \\
Semi-Steel & Petrobras & Marlim & 910 & 1994 \\
Semi-Concrete & Norsk Hydro & Troll West & 340 & 1996 \\
TLP-Steel & Shell & Mars & 893 & 1996 \\
TLP-Concrete & Conoco & Heidrun & 350 & 1995 \\
Ship & Petrobras & Barracuda & 843 & 1994 \\
\hline
\end{tabular}


表 4 世界の半潜水型生産システム

\begin{tabular}{|r|l|l|l|c|l|c|}
\hline No. & \multicolumn{1}{|c|}{ Field } & Operator & Location & W. D. (m) & \multicolumn{1}{|c|}{ FPF } & YEAR \\
\hline 1 & Marlim & Petrobras & Brazil & 910 & Petrobras 18 & 1994 \\
2 & Marlim & Petrobras & Brazil & 770 & Petrobras & 1997 \\
3 & Garden Banks 388 & Enserch & USA & 667 & Enserch Garden Banks (Glomar Biscay 1) & 1995 \\
4 & Bijupura/Salema & Petrobras & Brazil & 625 & Petrobras 13 & 1993 \\
5 & & North Sea & 600 & Spirit of Columbus & 1995 \\
6 & Marlim & Petrobras & Brazil & 600 & Petrobras 20 (Fortuna Ugland) & 1992 \\
7 & Marlim & Petrobras & Brazil & 600 & Petrobras 14 & 1989 \\
8 & Green Canyon 29 & Placid & USA & 456 & Penrod 72 & 1988 \\
9 & Marimba & Petrobras & Brazil & 423 & Petrobras 8 & 1993 \\
10 & Troll West & Norsk Hydro & Norway & 340 & Concrete FPF & 1996 \\
11 & Liuhua 11-1 & Amoco & China & 332 & Nan Hai Tiao Zhen (Sedco 705) & 1996 \\
12 & Njord & Norsk Hydro & Norway & 330 & Aker P-45 & 1997 \\
13 & Galoc & Alcorn & Philippine & 320 & Benvrackie (Aker H3) & 1988 \\
14 & Ewing Bank 914 & BP & USA & 300 & Lafitte Pincay & 1995 \\
15 & Albacola & Petrobras & Brazil & 252 & Petrobras 24 (Penrod 72) & 1993 \\
\hline
\end{tabular}

表 5 タンカー式生産システム

\begin{tabular}{|r|l|l|l|r|l|r|r|r|}
\hline & \multicolumn{1}{|c|}{ Field } & Operator & Location & W.D.(m) & \multicolumn{1}{|c|}{ Tanker } & Size(Ton) & Year & Mooring \\
\hline 1 & Barracuda & Petrobras & Brazil & 843 & Moraes & 64,825 & 1996 & Turret \\
2 & Foinaven & BP & UK & 454 & Petrojarl 4 & & 1996 & Turret \\
3 & Norne & Statoil & Norway & 375 & Tentech 850 S & 143,700 & 1997 & Turret \\
4 & West Linapacan & Alcorn & Philippines & 360 & EPSO II & 127,000 & 1992 & CALM \\
5 & Luihua & AMOCO & China & 332 & Lan shui EPSO & 70,000 & 1988 & CALM \\
6 & Albacora & Petrobras & Brazil & 230 & Moraes & 55,000 & 1987 & SBS \\
7 & Emerald & Sovereign & UK & 150 & Ailsa Craig & 160,000 & 1991 & Turret \\
8 & Hondo & Exxon & USA & 150 & & 50,000 & 1979 & SALM \\
9 & Lufeng 13 & JHN & China & 143 & & 123,000 & 1993 & Turret \\
10 & Tazerka & Shell & Tunisia & 143 & Tazerka & 210,000 & 1982 & SALS \\
11 & Donan & BP & UK & 140 & Seillean & 76,440 & 1992 & DPS \\
12 & Alba & Chevron & North Sea & 140 & & 120,000 & 1994 & Turret \\
13 & Griffin & BHP & Australia & 130 & Griffin Venture & 120,000 & 1994 & Turret \\
14 & Jabiru & BHP & Australia & 120 & Jabiru Venture & 160,000 & 1986 & Turret \\
15 & Garoupa & Petrobras & Brazil & 120 & & 54,000 & 1983 & CALM \\
\hline
\end{tabular}

$843 \mathrm{~m}$ に設置する㖕画であり, タンカー型の最大水深記 録を更新することになる。

\subsection{Tension Leg Platform (TLP)}

TLP に関する最初の技術開発は，1963年に英国の International Marine Development 社による“TRITON” と呼ばれるプロトタイプで氷樑 $30 \mathrm{~m}$ において試験され た。さらに，1967年には, Deep Oil Technology 社の X-1 プロトタイプの海洋実験がカリフォルニア蛀の 水深 $60 \mathrm{~m}$ において実施された。

このような実用化に向けた検討をへて，1984年に世界 最初の TLP が Conoco 社の Hutton 油田（水深 $148 \mathrm{~m}$ )
に設置され，現在順調に操業している。この成果を利用 して，1989年には，Conoco 社の Jolliet 油田（水深 536 m）に坑口装置のみの Tension Leg Wellhead Platform（TLWP）が設置された。

これらの成功は，TLPの選択をオイルカンパニーに 促し, Saga 社の Snorre 油田, Shell 社のAuger 油田, Mars 油田に TLP が採用された。Mars 油田の水深は, $983 \mathrm{~m}$ である。このようにTLPは，大水深における有 効な生産プラットフォームコンセプトとして諗識されつ つある。また, Conoco 社は, Heidrun 油田で浮体部分 をコンクリート製とした TLP 開発・設置することを 
表 6 TLP の開発

\begin{tabular}{|l|c|c|c|c|c|c|}
\hline \multicolumn{1}{|c|}{ Field } & Hutton & Jolliet & Snorre & Auger & Heidrun & Mars \\
\hline Area & North Sea & GOM & North Sea & GOM & North Sea & GOM \\
Country & UK & USA & Norway & USA & Norway & USA \\
Operator & CONOCO & CONOCO & SAGA & SHELL & CONOCO & SHELL \\
Status & 1984 & 1989 & 1992 & 1994 & 1995 & 1996 \\
W. D. (m) & 148 & 536 & 310 & 872 & 350 & 893 \\
Production & & & & & & \\
Rate (bpd) & 90,000 & 35,000 & 190,000 & 40,000 & 200,000 & 100,000 \\
Siots & 32 & 20 & 44 & 32 & 48 & 24 \\
Reservor (bpd) & $200 \mathrm{MM}$ & $44 \mathrm{MM}$ & $700 \mathrm{MM}$ & $220 \mathrm{MM}$ & $775 \mathrm{MM}$ & $700 \mathrm{MM}$ \\
Column & 6 & 4 & 4 & 4 & 4 & 4 \\
Size (m) & $65 \times 17.2$ dia. & $46.2 \times 12.2$ dia. & $63 \times 25$ dia. & $48.5 \times 22.5$ dia. & $26 \times 45$ dia. & $49.4 \times 20.3$ dia. \\
Columm Material & Steel & Steel & Steel & Steel & Concrete & Steel \\
Hull (m) & 57.7 & 44.8 & 64.5 & 45.7 & 96 & 81 \\
Deck Material & Steel & Steel & Steel & Steel & Steel & Steel \\
Tendon & $4 \times 4$ & $3 \times 4$ & $4 \times 4$ & $3 \times 4$ & $3 \times 4$ & $3 \times 4$ \\
(mm) & 260 Dia. & 690.6 Dia. & 914.4 Dia. & 660.4 Dia. & 1117.6 Dia. & 711.2 Dia. \\
Type & Thread & Thread & Thread & Weld & Thread & \\
Weight (ton) & 19,000 & 4,800 & 37,000 & 36,000 & 41,700 & 33,000 \\
Draft (m) & 32 & 24 & 37.5 & 29 & 77 & \\
Displacement (ton) & 70,147 & 18,447 & 105,500 & 66,000 & 171,600 & 48,000 \\
Anchor & Steel & Steel & Concrete & Steel & Concrete & Steel \\
Cost (MM US $\$$ ) & 1,300 & 400 & 4,730 & 1,100 & & \\
\hline
\end{tabular}

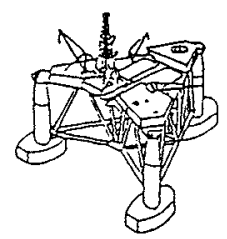

Sedev $135(1965)$

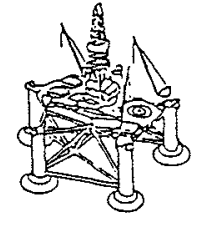

Pentagune (1969)

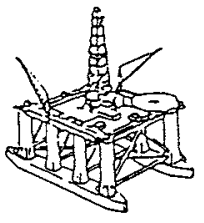

Aker fir-3 (1974)
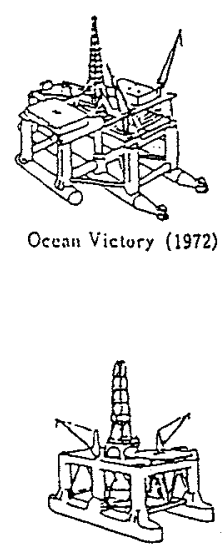

Binge 3000 (1982)
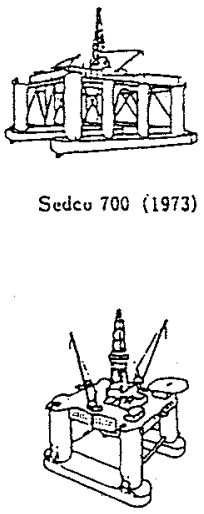

CVA 4000 (1983)

図 4 セミサブリグの変遷

計画して抢り，現在建造の最終段階に差し掛かってい る。さらに，オイルカンパニー数社がメキシコ湾に TLP を設置することを計画している（表 6 ）。

\section{4. 海洋掘削リグの発展}

半潜水型海洋掘削リグは，1961年にサブマーシブルり
グに浮力体をつけて半潜水型に改造したブルーウォー ター1 が最初である。1963年には, Odeco 社の Ocean Driller（変則三角型）が建造されている。これらをプ ロトタイプとして, 気象・海象条件の厳しい海域に適合 するために半潜水型海洋掘削りグは発展した。外観を参 考にすればその発展の経過が理解できるので，外観をま 


\begin{tabular}{|c|c|c|c|c|c|c|c|c|c|c|c|c|c|c|c|c|c|c|c|c|c|c|c|c|c|}
\hline 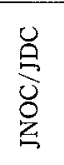 & & & 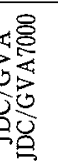 & 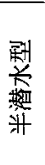 & & & & $\begin{array}{l}\text { 옹 } \\
\stackrel{9}{\Omega}\end{array}$ & 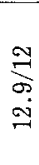 & $\infty$ & ণి & $\uparrow$ & 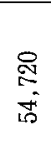 & $\begin{array}{l}8 \\
0 \\
5 \\
5\end{array}$ & $\begin{array}{l}8 \\
\text {. } \\
0 \\
0\end{array}$ & ฐ్ & $\sum_{0}^{\infty}$ & & & 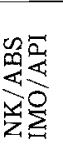 & & $\underset{\Im}{\rightrightarrows) ~}$ & $\infty$ & 我 & 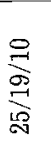 \\
\hline 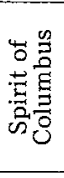 & 哭 & 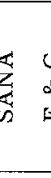 & 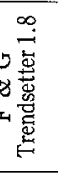 & 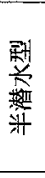 & $\stackrel{\mathscr{I}}{\dddot{\sim}}$ & 总 & 8 & $\stackrel{?}{8}$ & 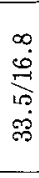 & $\infty$ & $\stackrel{\infty}{\stackrel{1}{~}}$ & & 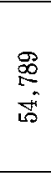 & $\begin{array}{l}\mathscr{0} \\
\stackrel{\sim}{0} \\
\text { ai }\end{array}$ & $\begin{array}{l}\mathscr{l} \\
\stackrel{0}{0} \\
\text { N }\end{array}$ & รี & & & 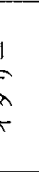 & 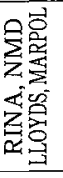 & & $\vec{\Xi}$ & $\stackrel{E}{E}$ & $\begin{array}{l}\stackrel{9}{9} \\
\dot{y}\end{array}$ & 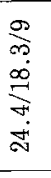 \\
\hline 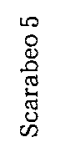 & $\stackrel{\mathbb{8}}{\stackrel{9}{\rightarrow}}$ & $\begin{array}{l}\overline{8} \\
\frac{\pi}{\pi} \\
\bar{\pi}\end{array}$ & 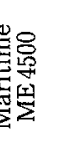 & 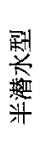 & 8 & $\begin{array}{l}8 \\
8 \\
\circ\end{array}$ & 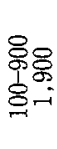 & 용 & 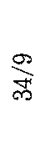 & 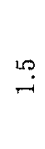 & & & $\begin{array}{l}8 \\
8 \\
F\end{array}$ & 总 & 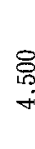 & เิ & 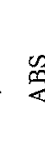 & 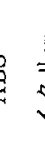 & $\frac{1}{2}$ & 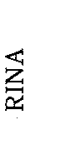 & & $\begin{array}{l}\infty \\
\stackrel{0}{\circ} \\
\stackrel{9}{g}\end{array}$ & $\begin{array}{l}\infty \\
\infty \\
\infty \\
0\end{array}$ & $\begin{array}{l}18 \\
\dot{c o s} \\
\dot{c o s}\end{array}$ & 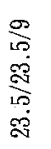 \\
\hline$\underset{\infty}{\mathbb{N}}$ & $\stackrel{\mathscr{g}}{9}$ & 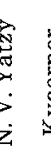 & 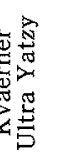 & 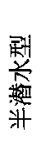 & $\&$ & $\begin{array}{l}8 \\
0 \\
6\end{array}$ & & $\stackrel{ }{ }$ & న్ & جִּ & శి & 0 & 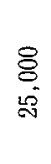 & $\begin{array}{l}\text { : } \\
\text { 心 } \\
\text { ल) }\end{array}$ & & & 党 & 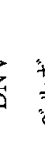 & $\begin{array}{l}1 \\
5 \\
5\end{array}$ & 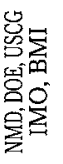 & & $\stackrel{2}{2}$ & 8 & 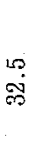 & 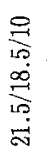 \\
\hline 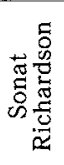 & $\begin{array}{l}\infty \\
\stackrel{\infty}{g} \\
\stackrel{\leftrightarrow}{\longrightarrow}\end{array}$ & & 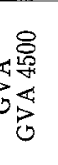 & 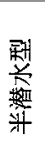 & @ & $\begin{array}{l}8 \\
0 \\
0=\end{array}$ & ర్రిం & $\stackrel{8}{8}$ & 10 & $\stackrel{10}{\infty}$ & จి & $\uparrow$ & $\begin{array}{l}8 \\
8 \\
\text { 站 }\end{array}$ & 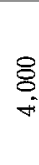 & छે & छ̊ & $z$ & 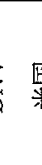 & 撞 & 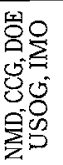 & & $\stackrel{\oplus}{\infty}$ & & & \\
\hline 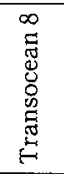 & $\stackrel{\circ}{\stackrel{\circ}{\rightleftarrows}}$ & 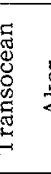 & 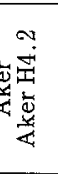 & 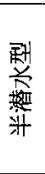 & 8 & $\begin{array}{l}\text { : } \\
\stackrel{0}{\circ}\end{array}$ & 8 & $\stackrel{8}{9}$ & ळి & & శి & 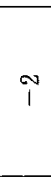 & 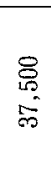 & $\begin{array}{l}8 \\
8 \\
-\end{array}$ & 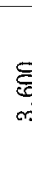 & ฐุ & Z & 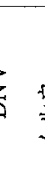 & 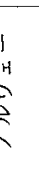 & 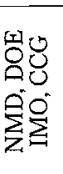 & & 음 & ֻั. & $\begin{array}{l}10 \\
\dot{80} \\
0\end{array}$ & 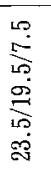 \\
\hline 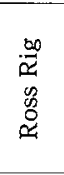 & $\stackrel{\mathscr{D}}{\stackrel{\circ}{二}}$ & 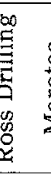 & 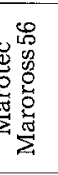 & 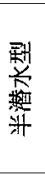 & $\S$ & 总 & & $\stackrel{?}{8}$ & $\stackrel{\infty}{\stackrel{\infty}{\infty}}$ & $\infty$ & & & 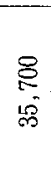 & : & §్ & 8 & 竞 & 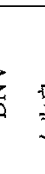 & 5 & 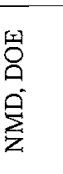 & & $\begin{array}{l}\dot{1} \\
\dot{\infty}\end{array}$ & 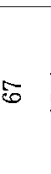 & $\begin{array}{l}\dot{s} \\
\dot{c o s}\end{array}$ & 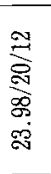 \\
\hline 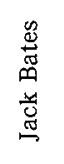 & 棁 & 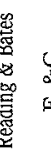 & 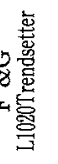 & 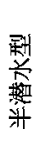 & $\stackrel{\mathscr{0}}{\stackrel{\mathrm{I}}{ }}$ & $\underset{8}{8}$ & & $\begin{array}{l}8 \\
8\end{array}$ & $\begin{array}{l}\infty \\
\stackrel{\infty}{\infty} \\
\stackrel{\infty}{\infty} \\
\infty \\
\infty \\
\infty\end{array}$ & $\infty$ & ఫิ & & 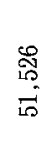 & $\underset{10}{\stackrel{8}{6}}$ & $\S$ & $\S$ & 4 & 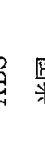 & $\begin{array}{l}\text { 票 } \\
\text { K }\end{array}$ & 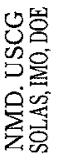 & & 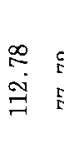 & 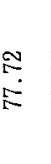 & $\begin{array}{l}\text { ठे } \\
\text { अं }\end{array}$ & 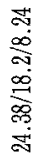 \\
\hline 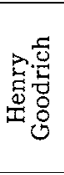 & $\stackrel{\mathscr{D}}{\stackrel{\mathscr{J}}{二}}$ & & 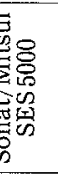 & 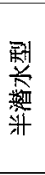 & 18 & $\begin{array}{l}8 \\
\stackrel{8}{0} \\
r=-1\end{array}$ & & $\begin{array}{l}\stackrel{\circ}{0} \\
\stackrel{0}{8}\end{array}$ & 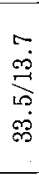 & 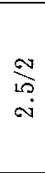 & ి్లి & $\uparrow$ & $\begin{array}{l}\stackrel{8}{F} \\
\stackrel{\sigma}{\sigma}\end{array}$ & 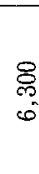 & बे & ఫ్ & 3 & 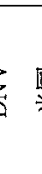 & 通 & 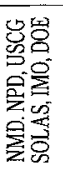 & & 总 & פ & $\begin{array}{l}\ddot{\theta} \\
\dot{\phi}\end{array}$ & 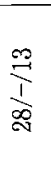 \\
\hline 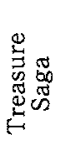 & $\stackrel{\mathscr{B}}{\stackrel{\mathscr{g}}{二}}$ & 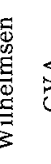 & 顽 & 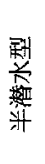 & 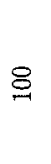 & 怘 & 丞 & $\stackrel{8}{9}$ & $\stackrel{\circ}{\circ}$ & & $\stackrel{10}{1}$ & & 只 & $\begin{array}{l}: \\
\text { \% } \\
\text { ळ }\end{array}$ & & ๙ & 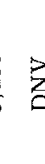 & 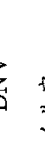 & E & 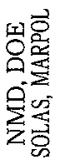 & & $\begin{array}{l}\mathscr{8} \\
\stackrel{P}{0} \\
\dot{\infty}\end{array}$ & $\overrightarrow{2}$ & $\vec{\forall}$ & 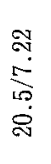 \\
\hline 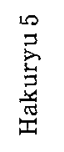 & & $g$ & 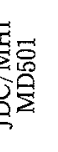 & 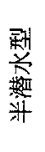 & 8 & 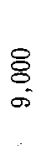 & 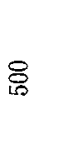 & $\begin{array}{l}8 \\
8 \\
8\end{array}$ & 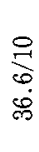 & ه & ণิ & $\uparrow$ & $\frac{\mathscr{8}}{\mathscr{8}}$ & ळ. & gీ & 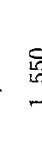 & $\frac{8}{2}$ & 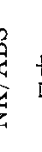 & 4 & 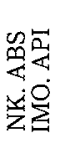 & & 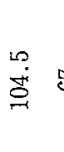 & 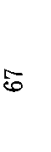 & 希 & $\begin{array}{l}\infty \\
\stackrel{\infty}{0} \\
\stackrel{0}{0} \\
\stackrel{8}{8}\end{array}$ \\
\hline $\begin{array}{l}\text { सम } \\
=\end{array}$ & 过 & $\begin{array}{l}13 \\
k \quad 3\end{array}$ & $r$ & $A$ & 楼 & 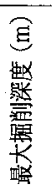 & 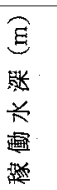 & 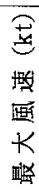 & 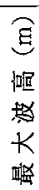 & 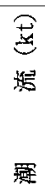 & $\begin{array}{l}\widehat{\theta} \\
\text { 呫 }\end{array}$ & 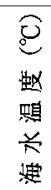 & 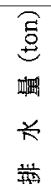 & 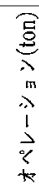 & 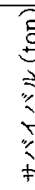 & . & 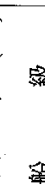 & 啹 & 策 & 㖹 & $\begin{array}{l}\text { 四 } \\
+1 \\
+1\end{array}$ & 焉 & 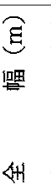 & $\begin{array}{l}\overparen{g} \\
\text { tu }\end{array}$ & $\begin{array}{l}\overline{\mathrm{g}} \\
\text { } \\
\text { 影 }\end{array}$ \\
\hline
\end{tabular}


とめてみた（図 4)。

Sedco-135型やペンタゴン型が登場したが移動性，鋼 材重量などの問題から4ロアーハル型が開発され，さら に半潜水型海洋掘削りグは，移動性，安定性，水深，搭 載能力などの条件を満足するために技術開発が進められ た。現在は，これらの条件を満たすために 2 ロアーハル 構造に統一され，コラム数も少ない夕イプが開発されて いる。8本コラム (Aker H3) 加ら6本コラム (Pacesetter, Bingo 3000) に発展して, さらに，4本コラム (GVA 4000) や5本コラム（Trendsetter) が登場し た。

次に,デッキロードについて見てみると, 1980年代に 入って，掘削作業時のデッキロードが4,000トンに達す る半潜水型海洋掘削リグが出現した。1980年代後半に は, 曳航, 掘削，サバイバルのすべての条件において デッキロードが，5,000トンを超える半潜水型海洋掘削 リグが建造されている。表 7 にセミサブ (半潜水) 型海 洋掘削りグの性能を示す。

技術的には，1980年のアレキサンダーキーランドの事 故を教訓にして, 半潜水型浮体の安全性には厳しい規則 が適用されるようになった（MODU A649）。厳しい規 則に適合し，加大水深に対応するシステム開発を目的 に石油公団から委託された「大水深対応早期生産試験シ ステムの経済性・適用性に関する調查」の一部として, 日本海洋掘削株式会社は，眝油機能を有する大型セミサ ブの概念設計を実施した。東南アジアの台風を考虑した 環境条件における稼㗢水深 $2,000 \mathrm{~m}$ 用のシステムであ る（図 5 )。構造の簡易化を図ってブレースを最小限に
し，動摇性能の優れた 4 本コラムタイプを採用している (戍6)。

\section{5. 海洋掘削システム}

\section{1 浮体技術}

(1) 浮体の最適化

浮体規模はその建造コストに直接影響する重要な問題 である。半潜水型浮体の動摇性能，作業性および移動性 に扔ける優位性を考慮した構造形式の最適化は, 係留設 備に大きな影響を与える。特に，大水深，厳環境におけ

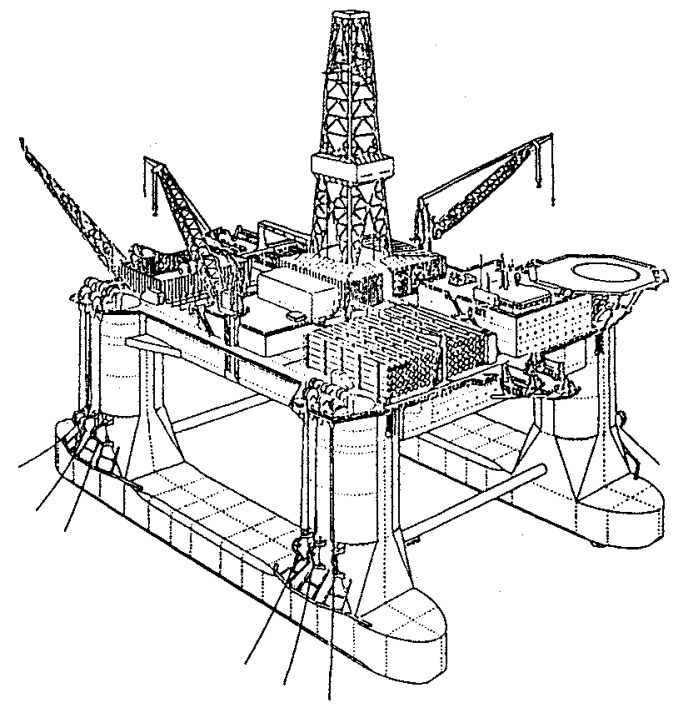

図 5 大水樑対応セミサブリグ (JNOC/JDC コンセプト)

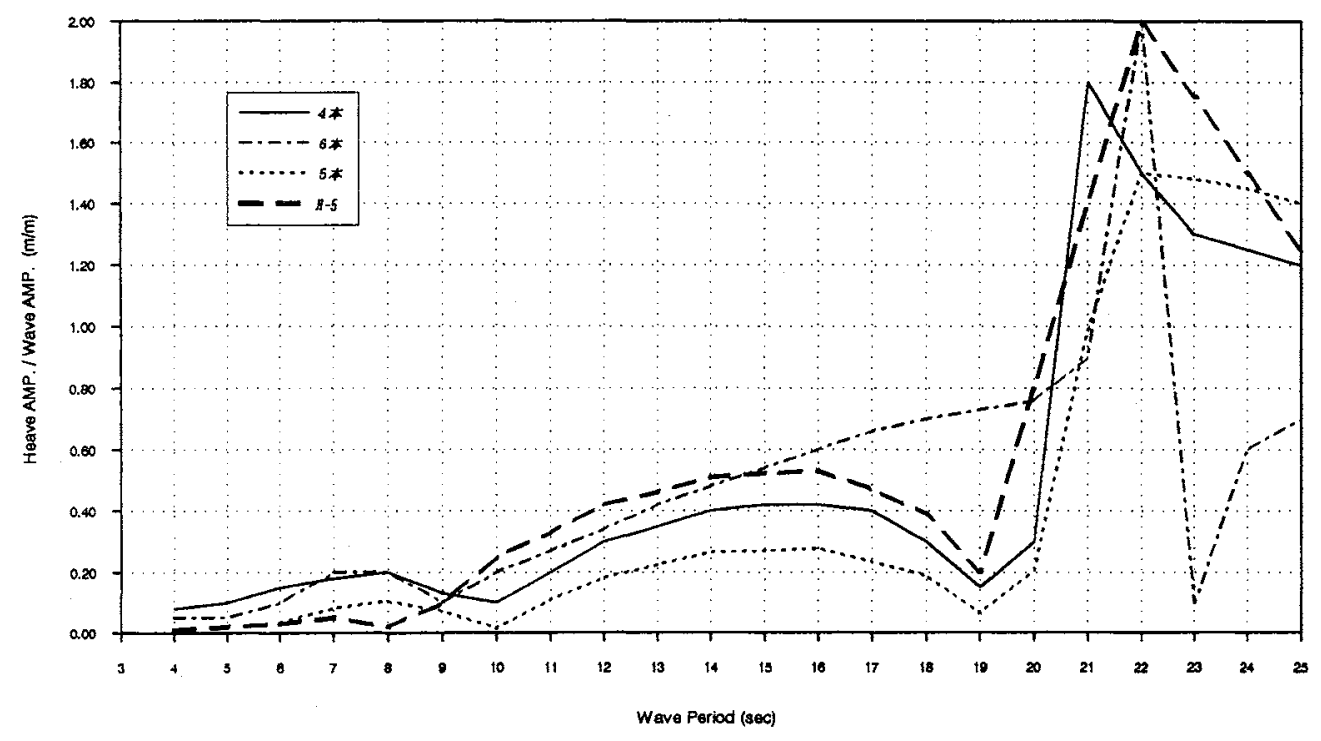

図6コラム数と動摇性能の関係 
る浮体最適化の問題は，古くて新しい課題であると言え る。また，浮体やデッキ構造の最適化を追求することに より，能力を縮小することなくコストを低減できる可能 性がある。1990年代のセミサブについて表 8 にとりまと めた。

（2）水平・斜ブレースの削減

解析技術の発展による構造に関する最適化およびボッ クス構造の採用による構造部材の削減が可能となりつつ ある。さらに，水平・斜ブレースについては仕口部の応 力集中, 曳航中の波力による振動問題などによる疲労を 考虑する必要がある。したがって，水平ブレースの削減 あるいは大口径化を検討するなどの対策が必要となる。

（3）ロワーハルの最適化

ロワーハルの形状は浮体の動摇性能・面航性に影響す る。有効性が確認されているドッグボーン型のロワー八 ルを採用しているセミサブがあり，さらなる形状の最適 化を図ることにより動摇性能の向上が期待される。恒久 的な生産システムにセミサブ型浮体を適用する場合は， 長期にわたる疲労の問題や貯油機能の付加を考慮したり ングポンッーンの採用が提案されている。

(4) コラム形状の最適化

コラム形状には抗力係数あるいは水線面積の增大を 図ったコンセプトが提案されている。コラム形状は定常 外力の減少, 安定性に影響するため, 最適化による形状 効果を研究する必要がある。

(5) 構造物の材質

ノルウェーにおいて従来の鋼製構造物に代わるコンク リート製の FPS が建造されている。熟練作業である仕 口部の溶接を必要としない利点ならびに建造コストの削 滅を可能とするコンクリート FPS は，Norsk Hydro 社 をオペレイターとして Troll West 油田に投入される。 構造物の材質に建造コストの削減を見いだした例として

表 8 1990年代のセミサブ

\begin{tabular}{|c|c|c|c|}
\hline & $\begin{array}{c}\text { Spirit of } \\
\text { Columbus }\end{array}$ & $\mathrm{P}-45$ & Troll Olje \\
\hline Owner & $\begin{array}{l}\text { Midland \& } \\
\text { Scottish }\end{array}$ & $\begin{array}{l}\text { Norsk } \\
\text { Hydro }\end{array}$ & Norsk Hydro \\
\hline Area & North Sea & $\begin{array}{l}\text { North Sea } \\
\quad \text { Njord }\end{array}$ & $\begin{array}{c}\text { North Sea } \\
\text { Troll }\end{array}$ \\
\hline Status & $\begin{array}{c}1995 \\
\text { Available }\end{array}$ & 1997 & 1996 \\
\hline 水深 $(\mathrm{m})$ & $100-500$ & 330 & 335 \\
\hline 材，質 & 鋼 製 & 鐝 製 & $\begin{array}{c}\text { コンクリート } \\
\text { 鋼 } \\
\end{array}$ \\
\hline 種 類 & 掘削十生産 & 掘削十生産 & 生 産 \\
\hline
\end{tabular}

石油技術協会誌 60 卷 5 号 (1995)
特記される(図 7)。

\section{2 係留技術}

(1) スラスターアシスト多点係留

定点保持技術には，カテナリ一係留，スラスターアシ ス卜係留，DPSがある。大水深におけるチエーンカテ ナリ一係留は，垂直荷重の増大が顕著であるため中間ブ イ方式，複合索あるいは織維ロープの採用が考えられ る。大水深対応係留は複合索方式あるいはスラスターア シストが掘削作業には有力である。セミサブリグにおけ る完全 DPS は，浮体規模あるいは環境条件，信頼性， コスト増大の観点からやや難点があると判断されてい る。係留ラインの設計には動的解析が不可欠であり，そ の選定には十分な事前解析を必要とする。

(2) 自動バラスト・アンカーテンション・スラスター アシストコントロール

係留技術は自動バラスト・アンカーテンション・スラ スターアシストの要素技術をまとめた総合的なオペレー ションインターフェースを確立する必要がある。技術開 発は各要素技術を自動化することにより安全を目指すこ とが重要である。

(3) ライザーパイプの係留システムへの影響

ライザーパイプは係留索と同様な拘束力を発生し，係 留システムの一部を構成していると考えられるため，ラ イザーパイプを考慮した検討が必要である。準静的解析 で倹討することが一般的であるが，動的解析を必要之 し，ライザーパイプを係留システムの一部として解析す る必要がある。ライザーパイプが水平方向のオフセット を制約するので，ライザーパイプ下端が海底から切り離 されたハングオフ時には，水平方向の拘束力が滅少して 水平移動量を堌加させる。したがって，係留解析はライ ザーパイプを含む総合的解析が必要である。

（4）破断時の過渡応答

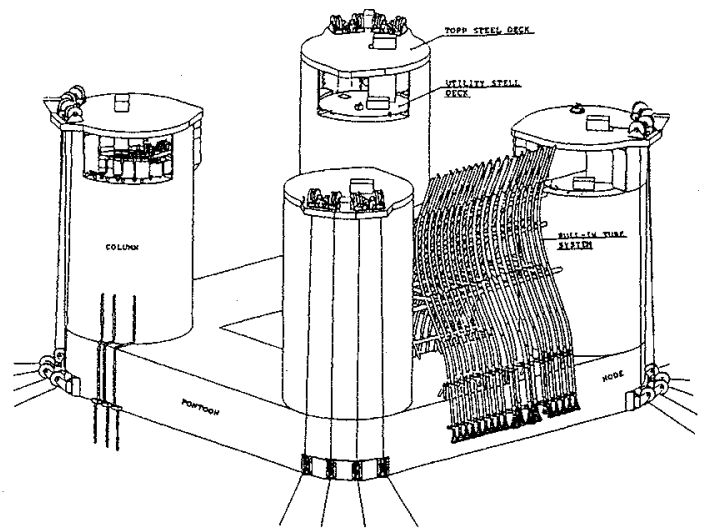

図 7 コンクリートセミサブリグ（OTC 7307） 
係留ラインの破断時における検討は船級協会において 決められている。係留ライン破断時の安全率の規定に よっては多大な係留設備が必要となる。したがって, 動 的係留解析の精度を向上することにより，動的要素が実 機によ゙のような影響を及ぼすか检討する必要がある。

(5) 高能率アンカー

大水深におりる定点保持で重要なポイントは海底に設 置するアンカーの把駐力を維持することである。高能率 アンカー選定のポイントは，土質の違いに対する沈用性 を持ち，かつ大水深における設置が容易であることであ る。また，大水深における作業性から自立型が望まし く, Bruce あるいは Stevpris 型が有力である。

(6) オートテンションシステムおよび高巻上能力コン ビネーションウインチ

アンカーシステムはオートテンションシステムの効率 的な機能および高巻上能力コンビネーションウインチに おけるプりテンションを考慮した機能を検討する必要が ある。

（7）高能率発電最適運転システムおよび効率スラス ター然料システム

発電システムは高能率発電最適運転システムの最適化 および効率スラスター燃料システムが要求される。

\section{3 サブシー技術}

(1) ガイドラインレス・ダイバーレスシステム

大水深掘削には，ガイドラインレス・ダイバーレスシ ステムが不可欠な機器である。大水深掘削は，ライザー の傾斜角あるいは接点变位・応力を超音波などにより計 測監視する必要がある。また，ライザー上端の上下動お らび变動張力を吸収するため，大容量のライザーテン ショナーが必要となり, 各機器の信頼性を考虑してその 容量を検討する必要がある。

(2) 2,000 m 水深におけるライザーパイプ動的挙動

静的挙動のみを考慮した場合には，十分に水深 2,000 $\mathrm{m}$ に执いて適用の可能性がある。しかし，大水深にお いては係留ラインの場合と同様に, 動的挙動の影響が大 きくなるため動的解析の重要性が指摘されている。また 渦励震, 綐振動の影響度を検討しておく必要がある。

(3) ハングオフ時におけるライザー下部ストレスジョ イント

ハングオフ時におけるライザー下部の応力集中により ストレスジョイントを採用するかどうかは外力条件によ り異なる。しかし，適用設計条件の汎用性および安全面 から考慮すると，ストレスジョイントについて検討して おく必要がある。

(4) フィルアップバルブの最適化

急激な逸泥などによるライザーパイプの圧潰を防ぐた
めのフィルアップバルブ（イコライジングバルブ）およ びライザ一内の泥水を維持するためブースターラインを 必要とする。フィルアップバルブの仕様，最適な設置值 置は課題として検討を加える必要がある。

(5) フレックスジョイント

大水深においては，ライザ一の変位に対応するためフ レックスジョイントを BOP の直上だけでなく，ライ ザーパイプの水面近くにも設置する必要がある。解析的 にはフフレックスジョイントに大きな角度が生じた場合 の切り離しについてシミュレーションすることが必要と なる。

(6) サブシーダイバータ

ライザーパイプ内へ坑底からガスが浸入した場合に対 処する Gas Handler 等をライザーパイプ上端あるいは 下端に取付けることにより，キックコントロールが容易 となる。

(7) リコイル

ライザーパイプの緊急切り離し作業時に使用され，テ ンショナーの張力によりライザーが掘削船に突き上げら れないように Riser Recoil Prevention System が考案 され，一部で活用されているが，汎用性，信頼性を考慮 すると油圧システムの最適化が望まれる。

(8) ライザー材質

大水深においてはライザーパイプの強度を向上させる 必要があるために, $80 \mathrm{~kg} / \mathrm{mm}^{2}$ 級の高張力鋼やチタ二 ウムを使用する場合がある。局部応力に対しては補強材 を巻き，単位局部応力を吸収することを考慮したハイブ リッドライザーの適用性を調查する必要がある。

(9) ライザーコネクター

大水深に拉いては，ハンドリングの時間を短縮する必 要がある。したがって，ライザーコネクターあ接続時間 の短縮および高耐荷重化に向けて，その技術仕様を向上 させる必要がある。

(10) BOP コントロールシステム

大水深に掠いてはレスポンスタイム（BOP の応答時 間）が問題となるため，電気信号によりパイロットバル ブを操作して液圧でバルブを開閉する方式が使われてい る。大通信容量, 高応答性能およびアンビリカルが長く なることから，Mux-EH 方式（マルチプレックス・エ レクトロ・ハイドロリック）が最適と考えられる。コン トロールシステムはアキュムレーターボトルを BOP ス タックに設置してレスポンスタイムを縮小したり, 非常 時に超音波を使って切離しができるようなシステム毛開 発されている。

大水潹開発にはサブシーアキュムレータの容量, パ ワーパッケージの方式, 光ファイバーケーブルの適用な 


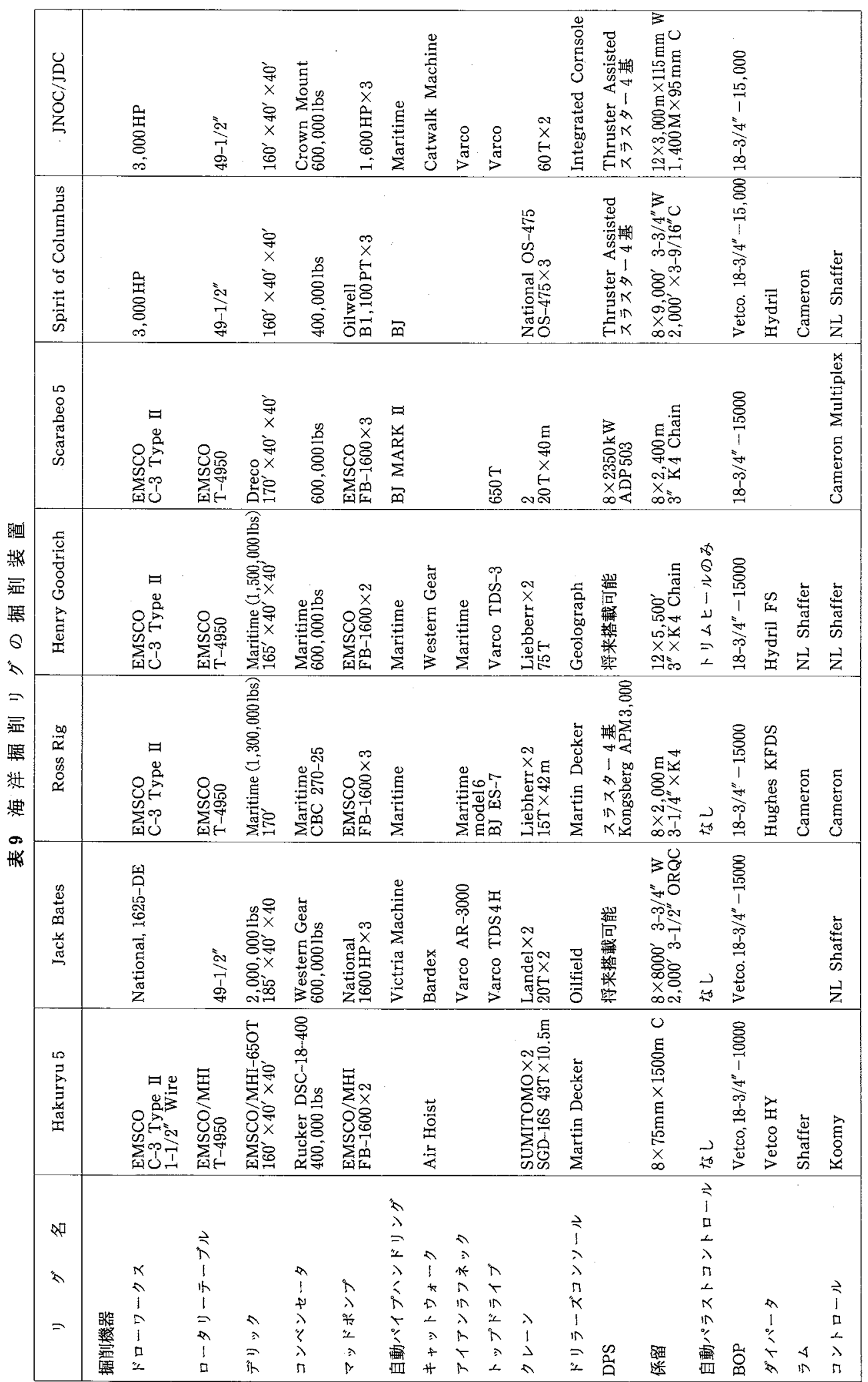


どの検討課題がある。大水深，高圧下におりる光，電 気，液圧複合コネクターの信頼性にはまだ問題が残され ている。

\section{(11) 浮力体}

浮力体は，エアカン式や Syntactic Foam 式などが使 われている。大水深に対応した適切な Syntactic Foam の此重, 浮力体の配置を考慮する必要がある。

(12) $\mathrm{BOP}$ ヒーティング

大水深における BOP スタック，BOP コントロールシ ステムは温度の低い海底に設置されるため，ハイドレー 卜対策上 BOP ヒーティングについて考慮する必要があ る。

\section{4 掘削設備}

代表的な海洋掘削りグおける掘削装置の一例を表 9 に 示す。大水深掘削のために掘削機器の能力が強化されて いる。吊上荷重が650トンの設計で，揚降管作業を軽減 させるために自動ハンドリングシステムを備えた海洋掘 削リグが増えつつある。近年, 自動掘削装置の研究・開 発が各機関, ベンダーで盛んに行われている。

各要素技術は，近年のコンピューターの発展にともな い様々な成果が举がっている。 MWD (Measuring While Drilling), LWD (Logging While Drilling), トップドライブ，アイアンラフネック，パイプハンドリ ング装置が主要な掘削機器になっている。このような安 全性に基づいた自動化・省力化が必要とされる。

(1) リグオートメーション

ライザーパイプのハンドリングシステムは，揚降時問 の短縮のため不可欠之なる。このようなリグォートメー ションは，ドリルフロアの安全性を目的に開発が進めら れているが, そのほかにす，オートンリッドコントロー ル, 自動バラストコントロール, APS (Auto Positioning System), 自動掘削のための坑内状況情報管理シス テムなどの総合的な自動化の研究・開発が求められてい る。

(2) アクティブコンペンセータ

従来のポジティブコンペンセータは静的制御である が，海洋においては動的制御を採用することによる有利 性がある。自然猿境条件に応じた制御が可能となること によって安全性，信頼性が向上することで，大水深にお ける荷重コントロールを可能とする。

（3）コントロールシステムの一体化

掘削をコントロールする場合は，ハンドリング，泥水 状況，ソリッドコントロール，ライザーモニタリング, BOP な゙を一体化することにより判断材料を一極化さ せ，集中制御を実施するための統合技術の研究が課題と なる。
（4） $\mathrm{AC}$ 機器の適用性

従来は DC 機器が一般的に掘削設備として多用されて きた。最近ではAC 機器の適用性が見直され機器の重量 低減，保守の容易性から研究が進められている。

北海の Troll,Ekofisk,Britannia などの油田において $\mathrm{AC}$ 機器が選定されている。 $\mathrm{AC}$ 機器は, $\mathrm{DC}$ 機器に比 較して効率, トルク，オーバーロード能力, 冷却ダクト の削減に優れている。さらに, $\mathrm{AC}$ 機器は, 制止時に最 大トルクを掛けることができる。つまり，ドローワーク スにおいて荷重を長時問保持できる利点は掘削作業にお いて重要なことである。また低回転による循環，摩擦損 失が大きい大水深ウェルコントロールなどでは, 回転, トルクの制御に効果を発揮する。また，保守の容易性は 操業費の低隇に寄与できるものである。

（5）ソリッドコントロールの自動化および最適化

ソリッド除去は，回収されたソリッドの粒度が違うた めに様々な装置を組み合わせて行う。泥水に応じて最適 な組み合わせができる設備を備える必要がある。

海洋掘削りグは, 一般的に掘削能力が 6,000 9,000 $\mathrm{m}$ と大きく，大部分の海洋掘削リグのマッドポンプは， $1,600 \mathrm{HP}$ クスのトリプレックスポンプを搭載してい る。最近は大水深掘削に備え, 通常 2 台のマッドポンプ から 3 台のマッドポンプを備えたリグが登場している。

調泥，偱環における自動化により省力化を念頭におい たコンセプトは今後の研究対象として進められる必要が ある。

(6) 総合排水システム

環境問題が叫ばれている現在，石油業界に招いて総合 排水問題を拔きにすることはできない。現在，泥水に関 しては地中化処分について研究されており, 総合排水シ ステムの装備を視野に入れておく必要がある。

\section{(7) 総合評価技術}

要素技術は個別開発要素が非常に強く，各要素技術を トータルパッケージとしてまとめる場合，統合技術が必 要である。

\section{6. 大水深掘削リグの将来展望}

海洋掘削りグの安全性の強化を目的とした船級条項の 改訂は，リグの建造・改造費用を一層堌大させるため市 況の回復が依然として低迷している現在，採算性に強く 影響を及ぼしている。さらに，市況から判断するとりグ 総数が毎年減少して需要・供給のバランスが取れるのは 2000年以後になる見通しであるが，現在の油佂，デー レートの低迷はドリリングコントラクターをしてリグの 建造意欲を失わせている。その一方で石油開発が大水深 に向かっているのは事実であり，さらに大水深に対応で 
きる掘削リグ数が限られているため建造あるいは改造が 求められ，業界全体に対応を余儀なくされている。

この上うな状況において民間レベルで大水深開発を進 めることは難しく，大水深技術の発展のためには国の施 策に大きなウェートを置かざるを得ない。我が国が大水 樑掘削リグを所有して国際的な大水深掘削でのイニシア ティブをとることの意義は大きいと考えられる。

ハード的に考えればセミサブ型，ジャッキアップ型が
主流であることに変わりなく，搭載機器については自動 化・省力化, 安全性・信頼性あるいは搭載重量の増大, 撖海域に対応するハードの効率化および定価格化が求め られる。最近大水深での，ガス八イドレート開発が話題 になり「21世紀の開発」として大水深対応や技術開発が 望まれていることから，大水樑技術の今後一層の発展を 期待するものである。 